\title{
Effects of Launaea taraxacifolia on Lead - Induced Hepatotoxicity in Rats
}

\section{Abstract}

Lead is a cumulative, multi-systemic toxicant which affects major body systems; it is associated with number of changes that include impairment of liver function. This study investigated the effects of extract of Launaea taraxacifolia on subchronic lead poisoning in adult wistar rats; it evaluated the effects of one of dimecarptosuccinic acid (DMSA), Vitamin C (VC); and combination therapy (DMSA $+\mathrm{VC}, \mathrm{DMSA}+\mathrm{LT}$ ) on sub-chronic lead poisoning in adult rats. This was with a view to providing scientific basis for the use of L. taraxacifolia in the management of lead poisoning. Sixty rats (180-200 g) of both sex were randomly grouped into ten $(n=6)$. One group was allowed free access to distilled water only, while eight groups were allowed free access to lead acetate $(2 \mathrm{mg} / \mathrm{ml})$ in drinking water, for 5 weeks consecutively. Seven out of the eight groups were later administered Launaea taraxacifolia extract (50, 100 and $200 \mathrm{mg} / \mathrm{kg}$, p. o), DMSA, DMSA + LT, DMSA + VC and VC only for 21 days consecutively. The tenth group was administered LT $(100 \mathrm{mg} / \mathrm{kg})$ for 21 days, and later allowed free access to lead acetate in drinking water $(2 \mathrm{mg} / \mathrm{ml})$ for 5 weeks. Blood sample was collected and analysed for blood lead level (BLL), urine lead level (ULL), Alanine transaminase (ALT), Aspartate transaminase (AST), antioxidant activity of the extract [Reduced gluthatione (GSH), catalase and superoxide dismutase (SOD)] on day 20 and 22. Liver was harvested and processed for histological study: There was significant decrease in $B L L, A L T, A S T$ and glucose level in lead exposed rats treated with $L T(100 \mathrm{mg} / \mathrm{kg})$, however, combination of DMSA with LT or VC showed marked improvement than LT, DMSA or VC alone. GSH, SOD and catalase level were significantly increased in lead exposed rats treated with LT $(p<0.05)$. Micrograph of the liver revealed remarkable improvement in the lead exposed rats treated with LT. In conclusion, leaf extract of Launaea taraxacifolia has ameliorative and preventive effect on hepatotoxicity of lead poisoning, thereby supporting its ethno medicinal use in the management of poisoning.

Keywords: Dimecaptosuccinic acid; Lead poisoning; Launaea taraxacifolia; Vitamin C

Received: October 12, 2018; Accepted: October 27, 2018; Published: November 03, 2018

\section{Introduction}

Lead $(\mathrm{Pb})$ is a soft, malleable, inelastic heavy metal. It is one of the abundant heavy metals found in our environment, majorly in soil and water [1]. Lead is a multi-systemic toxicant when it accumulates [2]. It is hazardous to health. Environmental contamination by lead generated from human activities has become an evident problem and remain a global public health

\section{Omotayo A. Eluwole ${ }^{1 *}$, Oluwole I. Adeyemi ${ }^{2}$ and Moses A. Akanmu ${ }^{2}$}

1 Department of Medical Pharmacology and Therapeutics, College of Health Sciences, Obafemi Awolowo University, Ile- Ife, Osun State, Nigeria

2 Department of Pharmacology, Faculty of Pharmacy, Obafemi Awolowo University, Ile-Ife, Osun State, Nigeria

\section{*Corresponding author: Omotayo A \\ $\equiv$ tayoeluwole@gmail.com}

Tel: $+234-7062280231$

Department of Medical Pharmacology and Therapeutics, Faculty of Basic Medical Sciences, College of Health Sciences, Obafemi Awolowo University, Ile-Ife, Osun State, Nigeria

Citation: Eluwole OA, Adeyemi OI, Moses Akanmu A (2018) Effects of Launaea taraxacifolia on Lead - Induced Hepatotoxicity in Rats. J Heavy Met Toxicity Dis Vol.3 No.2:6 
the effects of free radicals. Ascorbic acid is an example of nonenzymatic antioxidant that is generally regarded as a primary first-line protective agent that repairs or eliminate free radicals, it also possesses chelating properties, it has been reported that it protects cells from oxidative stress, the protective effect of vitamin C also reflect on cell apoptosis $[5,6]$.

However, Launaea taraxacifolia, known as Afican/Wild lettuce in English language, Efó-Yanrín or odứndứn- odo (Yoruba), namijindayii or nomenbarewa (Hausa), is a popular plant in southwest Nigeria used traditionally for treatment of poisoning [7]. LT is a vegetable that is nutritionally rich and safe for consumption. Studies on its nutritional value and phytochemical constituents revealed that extracts of its leaves were rich in potassium, calcium, magnesium, ascorbic acid, tannins, vitamins, minerals, proteins, essential fatty acids, fibre contents and flavonoids. It also contains appreciable levels of $\beta$-carotene, ascorbic acid, $\alpha$-tocopherol and riboflavin. It is a vegetable that is nutritionally rich and safe for consumption $[8,9]$.

Launaea taraxacifolia leaves have been proven to have low calories, significant antioxidant, antiviral activity, anticancer potentials $[9,10]$. Moreover, LT was reported to have ameliorated cisplastin - induced hepatorenal toxicity, testicular dysfunction, lead induced neurological and haematological alterations [1113]. However, effects of LT on lead induced hepatotoxicity are yet to be reported.

\section{Materials and Methods}

\section{Sample collection}

Lauanae taraxacifolia was collected at Oranfe area of lle-Ife, Osun State, Nigeria. It was identified and authenticated by a taxonomist at the Department of Botany, Obafemi Awolowo University, Ile-Ife, Osun State. A voucher specimen (number is IFE/17473) was deposited at the herbarium. Leaves collected (300 g) were dried, weighed. It was extracted with methanol, to obtain methanol extract. The yield was $28.27 \mathrm{~g}$ which is $9.42 \% \mathrm{w} / \mathrm{w}$ of the powdered material. The powdered form was subjected to cold extraction.

\section{Experimental animal}

Seventy three (73) rats of both sexes, weighing between $180-$ $200 \mathrm{~g}$ were used for this study. The animals were bred locally in the animal house of the Faculty of Basic Medical Sciences, Obafemi Awolowo University, Ile-Ife, Osun State, Nigeria. They were housed in metabolic cages under conventional laboratory condition, fed with standard laboratory chow and water given ad libitum. They were allowed to acclimatize (in metabolic cages) for 2 weeks before drug administration. LD50, an index of acute toxicity was determined using the Lorkes (1983) method.

\section{Lead induction}

Lead toxicity was induced through ingestion of lead acetate in drinking water for 5 weeks consecutively. Lead acetate as a powder was dissolved in distilled water $2 \mathrm{mg} / \mathrm{ml}$ daily [11]. Animals drank from the graduated water bottle and the decrement in the amount of water over 24-h was measured by subtracting the day's reading from the amount from previous day.

\section{Experimental group}

Sixty animals were randomly divided into ten groups $(n=6)$. Group I were allowed free access to drink distilled water daily for 8 weeks. Group II were allowed free access to lead acetate in drinking water $(2 \mathrm{mg} / \mathrm{ml}$, p. o) for 5 weeks and distilled water daily for 21 days. Group III were administered L. taraxacifolia $(100 \mathrm{mg} /$ $\mathrm{kg}, \mathrm{p} . \mathrm{o})$, for 21 days, initially and allowed to drink lead acetate (200 mg/100 ml, p. o.), for 5 weeks consecutively. Group IV were allowed to drink lead acetate $(2 \mathrm{mg} / \mathrm{ml}, \mathrm{p}$. o), for 5 weeks and treated with the extract ( $50 \mathrm{mg} / \mathrm{kg}, \mathrm{p}$. o), for 21 days. Group V: Allowed free access to lead acetate in drinking water and treated with the extract $(100 \mathrm{mg} / \mathrm{kg}$, p. o.), for 21 days. Group VI were allowed free access to lead acetate in drinking water $(2 \mathrm{mg} / \mathrm{ml}, \mathrm{p}$. o), for 5 weeks and treated with L. taraxacifolia extract $(200 \mathrm{mg}$ / $\mathrm{kg}$, p. o.), for 21 days. Group VII were allowed free access to lead acetate in drinking water $(2 \mathrm{mg} / \mathrm{ml}$, p.o $)$, for 5 weeks, and treated with oral dimecaptosuccinic acid (DMSA) only, $30 \mathrm{mg} / \mathrm{kg} /$ day for the first 5 days, then $20 \mathrm{mg} / \mathrm{kg}$ per day for the next 14 days of the experiment. Group VIII were allowed free access to lead acetate in drinking water $(2 \mathrm{mg} / \mathrm{ml}, \mathrm{p}$. o) for 5 weeks and treated with the extract ( $100 \mathrm{mg} / \mathrm{kg}, \mathrm{p} . \mathrm{o}$ ), for 21 days, and oral DMSA (same dose with Group VII) for the same period. Group IX were allowed free access to lead acetate in drinking water $(2 \mathrm{mg} / \mathrm{ml}, \mathrm{p} . \mathrm{o})$ for 5 weeks and treated with oral DMSA (same dose with Group VII) and ascorbic acid (100 mg/kg, p. o), for 21 days. Group X were allowed free access to lead acetate in drinking water $(2 \mathrm{mg} / \mathrm{ml}$, p. o), for 5 weeks and treated with ascorbic acid only, $100 \mathrm{mg} /$ kg orally for 21 days. Animals were further sacrificed; liver were harvested and processed for histological study.

\section{Biochemical analysis}

Liver function tests: The serum was assayed to determine alanine transaminase (ALT) and aspartate transaminase (AST), blood glucose and albumin level. Measurement of the liver function tests were done by spectrophotometer using Randox ${ }^{\circledR}$ kit (Randox laboratories, Crumilin, Co. Antrim UK). AST and ALT were analysed according to Reitman and Frankel method (1957). Serum albumin and glucose were analysed using the method described by Grant et al.

Estimation of Alanine Transaminase (ALT) activity: To determine $A L T$, serum $(0.1 \mathrm{ml})$ was pipette into test tubes in triplicates and mixed with $0.5 \mathrm{ml}$ of $\mathrm{R} 1$ solution $(2 \mathrm{mM} \alpha$ - Ketoglutarate, $0.2 \mathrm{M} \mathrm{DL}$ - Aspartate in Phosphate buffer $0.1 \mathrm{M} \mathrm{pH} 7.4$ ), it was incubated for $30 \mathrm{~min}$ at $37^{\circ} \mathrm{C}$. At the end of incubation, $0.1 \mathrm{ml}$ of 2,4 - dinitrophenylhydrazine was added, mixed thoroughly, and allowed to stand for $20 \mathrm{~min}$ at $25^{\circ} \mathrm{C}$, after which $1 \mathrm{ml}$ of 0.4 $\mathrm{mol} / \mathrm{dm}^{3} \mathrm{NaOH}$ was added. The change in colour development was measured spectrophotometrically using a Cintral UV Spectrophotometer at a wavelength of $500 \mathrm{~nm}$ against a blank containing buffered substrate and 2, 4-dinitrophenylhydrazine only. The activity of the enzyme was extrapolated from a calibration curve obtained from an absorbance-enzyme activity table of values provided by the manufacturer in the kit. The enzyme activity was expressed as $\mathrm{U} / \mathrm{I}$. 
Estimation of Aspartate Transaminase (AST) activity procedure: AST was estimated by the method of (Reitman and Frankel 1957). To $20 \mu \mathrm{l}$ of serum, $0.5 \mathrm{ml}$ of R1 (2 mM $\alpha$ - oxoglutarate, $0.2 \mathrm{M} \mathrm{DL}$ Aspartate in Phosphate buffer $0.1 \mathrm{M} \mathrm{pH} \mathrm{7.4)} \mathrm{was} \mathrm{added.} \mathrm{This} \mathrm{was}$ mixed and incubated for $30 \mathrm{~min}$ at $37^{\circ} \mathrm{C}$. At the end of incubation, $0.5 \mathrm{ml}$ of R2 (2, 4-dinitrophenylhydrazine) was added, mixed thoroughly, and allowed to stand for $20 \mathrm{~min}$ at $25^{\circ} \mathrm{C}$, after which $1 \mathrm{ml}$ of $0.4 \mathrm{~mol} / \mathrm{dm}^{3} \mathrm{NaOH}$ was added. The absorbance was read at $500 \mathrm{~nm}$ against a blank containing buffered substrate and 2, 4 -dinitrophenylhydrazine only. The results were expressed as $\mathrm{U} / \mathrm{I}$.

Serum albumin: Albumin level was determined by adding $10 \mu \mathrm{l}$ of distilled water, $10 \mu \mathrm{l}$ of serum and $3 \mathrm{ml}$ of BCG reagents (Succinate buffer, bromocresol green and brij 35). The reaction mixture was incubated for $5 \mathrm{~min}$ at $20-25^{\circ} \mathrm{C}$. Absorbance of sample and the standard (distilled water) were measured against blank at 630 $\mathrm{nm}$. Albumin concentration was expressed as $\mathrm{mg} / \mathrm{dL}$.

Albumin concentration $=\mathrm{A}$ sample $/ \mathrm{A}$ standard $\mathrm{x}$ concentration of standard.

Serum glucose: Serum glucose was assayed using the method of (Barham et al.,). To $10 \mu \mathrm{l}$ of serum, $1 \mathrm{ml}$ of reagent buffer (Phosphate buffer $0.1 \mathrm{~mol} / \mathrm{l}, \mathrm{pH} 7.0$, phenol $11 \mathrm{mmol} / \mathrm{l}, 4$ aminophazone $0.77 \mathrm{mmol} / \mathrm{l}$, glucose oxidase $1.5 \mathrm{kU} / \mathrm{l}$, peroxidase $1.5 \mathrm{kU} / \mathrm{l})$ was added. The standard was prepared by adding $1 \mathrm{ml}$ of reagent buffer to $20 \mu \mathrm{l}$ of Glucose $(5.49 \mathrm{mmol} / \mathrm{l})$. This was taken as the standard. Absorbance of glucose at $590 \mathrm{~nm}$ was determined after $10 \mathrm{~min}$ of incubation at $20^{\circ} \mathrm{C}$. This was measured against the blank containing reagent buffer and distilled water only. The glucose concentration was expressed as $\mathrm{mg} / \mathrm{dL}$.

Glucose concentration $=\mathrm{A}$ sample $/ \mathrm{A}$ standard $\mathrm{x}$ concentration of standard X 100

\section{Assessment of antioxidant level}

Glutathione reductase: Reduced glutathione (GSH) was measured by the method of Beutler and Kelly (1963). The amount of GSH is expressed in $\mathrm{mg} / 100 \mathrm{~g}$ tissue.

Catalase (CAT): Catalase activity was estimated determined in erythrocyte serum using Aebi's method (Aebi, 1984). is expressed as units per milligram of protein.

Superoxide dismutase (SOD): The SOD level in the blood was determined using Mccord and Fridovich method. The serum level of SOD is expressed as units/mg protein.

\section{Histopathological analysis}

The animals were further dissected and sectioned. Liver were carefully excised and weighed. They were fixed in $10 \%$ formal saline solution to prevent putrefaction and autolysis. They were counter stained with eosin and viewed under the microscope with photomicrographs taken with a Leica DM750 Camera Microscope (X400).

\section{Statistical analysis}

The results obtained were presented as mean \pm SEM (Standard error of the mean). Comparisons were made between treated and control groups using Student's t-test. One-way ANOVA was used to analyse significant difference of means with Student Newman Keuls post hoc test for multiple comparisons. Results obtained were presented as mean \pm SEM (standard error of the mean), level of significance was taken as $p<0.05$.

\section{Results}

Table 1 shows the Blood Lead Level (BLL) and Urine Lead Level $(U L L)$; there was significant increase in $(p<0.05)$ value of $B L L$ of the group administered lead only ( $\mathrm{Pb}$ only) when compared with the group treated with distilled water only (VEH) while there was significant decrease in $(p<0.05)$ value of $B L L$ of all the treated groups when compared with $\mathrm{Pb}$ only. Moreover, there was significant decrease in $(p<0.05)$ value of $B L L$ of the groups treated with combination therapy (DMSA+LT and DMSA+VC) when compared with group treated with DMSA only. On the other hands, urine lead level (ULL) was significant increase $(p<0.05)$ value of ULL in all the treated groups when compared with $\mathrm{Pb}$ only, but there was no significant decrease in group treated with VEH when compared with $\mathrm{Pb}$ only. Meanwhile, $(p<0.05)$ value of ULL in group treated with Vitamin C only (VC only) significantly decreased when compared with DMSA + VC.

Table 2 shows the effects of L. taraxacifolia on some liver function tests [Liver enzymes; alanine transaminase (ALT) and aspartate transaminase (AST)], albumin and fasting blood glucose] on sub chronic lead poisoning. The results revealed that, there was significant increase $(p<0.05)$ in liver enzymes

Table 1 Effect of L. taraxacifolia on Blood and Urine Lead Level in Sub Chronic Lead Poisoning.

\begin{tabular}{|c|c|c|}
\hline \multicolumn{3}{|c|}{ MEAN VALUES \pm SEM } \\
\hline GROUPS & LEAD IN URINE ( $\mu \mathrm{mol} / \mathrm{I})$ & $\begin{array}{l}\text { LEAD IN BLOOD } \\
(\mu \mathrm{mol} / \mathrm{I})\end{array}$ \\
\hline VEH (No Lead) & $0.009 \pm 0.002$ & $0.010 \pm 0.002$ \\
\hline $\mathrm{Pb}$ only. & $0.005 \pm 0.004$ & $0.030 \pm 0.002 *$ \\
\hline $\mathrm{Pb}+50 \mathrm{mg} / \mathrm{kg} \mathrm{LT}$ & $0.020 \pm 0.001 \#$ & $0.010 \pm 0.001 \#$ \\
\hline $\mathrm{Pb}+100 \mathrm{mg} / \mathrm{kg} \mathrm{LT}$ & $0.020 \pm 0.001 \#$ & $0.010 \pm 0.001 \#$ \\
\hline $\mathrm{Pb}+200 \mathrm{mg} / \mathrm{kg} \mathrm{LT}$ & $0.020 \pm 0.001 \#$ & $0.008 \pm 0.001 \#$ \\
\hline $\mathrm{Pb}+\mathrm{LT}^{*}$ & $0.020 \pm 0.003 \#$ & $0.007 \pm 0.002 \#$ \\
\hline Pb + DMSA Only & $0.017 \pm 0.001 \#$ & $0.010 \pm 0.003 \#$ \\
\hline $\mathrm{Pb}+\mathrm{DMSA}+\mathrm{LT}$ & $0.020 \pm 0.001 \#$ & $0.005 \pm 0.002 \#=$ \\
\hline $\mathrm{Pb}+\mathrm{DMSA}+\mathrm{VC}$ & $0.020 \pm 0.003 \#$ & $0.006 \pm 0.002 \#=$ \\
\hline $\mathrm{Pb}+\mathrm{VC}$ Only & $0.030 \pm 0.002 \# \bullet$ & $0.008 \pm 0.002 \#$ \\
\hline
\end{tabular}

The above table shows the effect of $L$. taraxazifolia on blood and urine lead level in sub chronic lead poisoning :

$\mathrm{VEH}=$ Distilled water only,

$\mathrm{Pb}=$ Lead,

DMSA = Dimecarptossuccinic acid

$\mathrm{VC}=$ Vitamin $\mathrm{C}$

$\mathrm{LT}=$ Launaea taraxacifolia

LTP $=100 \mathrm{mg} / \mathrm{kg}$ of Launaea taraxacifolia before lead treatment

$*$ significant $\mathrm{p}$ value when compared with VEH

\# = significant $\mathrm{p}$ value when compared with $\mathrm{Pb}$ only

- = significant $p$ value when compared with DMSA only treated group

- = significant $p$ value when compared with DMSA + VC treated group.

Note: Lead level discovered in drinking water and feed were $0.0023 \mathrm{mg} /$ $\mathrm{dl}$ and $0.0015 \mathrm{mg} / \mathrm{dl}$ respectively. 
Table 2 Effects of L. taraxacifolia on Some Liver Function Test in Sub Chronic Lead Poisoning.

\begin{tabular}{|c|c|c|c|c|}
\hline \multicolumn{5}{|c|}{ MEAN VALUES \pm SEM } \\
\hline GROUPS & ALT ( $\mu \mathrm{mol} / \mathrm{I})$ & AST ( $\mu \mathrm{mol} / \mathrm{I})$ & ALBUMIN $(\mu \mathrm{mol} / \mathrm{l})$ & GLUCOSE ( $\mu \mathrm{mol} / \mathrm{I})$ \\
\hline VEH (No Lead) & $0.28 \pm 0.06$ & $0.21 \pm 0.02$ & $4.03 \pm 0.34$ & $0.10 \pm 0.02$ \\
\hline $\mathrm{Pb}$ only & $0.45 \pm 0.05^{*}$ & $0.42 \pm 0.04 *$ & $3.88 \pm 0.18$ & $0.03 \pm 0.02 *$ \\
\hline $\mathrm{LT}^{*}$ & $0.16 \pm 0.01 \#$ & $0.20 \pm 0.04 \#$ & $4.00 \pm 0.09$ & $0.03 \pm 0.01$ \\
\hline $\mathrm{Pb}+50 \mathrm{mg} / \mathrm{kg}$ & $0.12 \pm 0.02 \#$ & $0.10 \pm 0.02 \#$ & $4.40 \pm 0.13$ & $0.04 \pm 0.01$ \\
\hline $\mathrm{Pb}+100 \mathrm{mg} / \mathrm{kg}$ & $0.08 \pm 0.02 \# 0$ & $0.08 \pm 0.01 \# 0$ & $3.49 \pm 0.19$ & $0.06 \pm 0.01 \#$ \\
\hline $\mathrm{Pb}+200 \mathrm{mg} / \mathrm{kg}$ & $0.13 \pm 0.01 \#$ & $0.18 \pm 0.03 \#$ & $4.28 \pm 0.10$ & $0.03 \pm 0.01$ \\
\hline $\mathrm{Pb}+\mathrm{DMSA}$ only & $0.34 \pm 0.04 \#$ & $0.24 \pm 0.05 \# \square$ & $3.97 \pm 0.21$ & $0.06 \pm 0.01 \#$ \\
\hline $\mathrm{Pb}+\mathrm{DMSA}+\mathrm{LT}(100 \mathrm{mg} / \mathrm{kg})$ & $0.32 \pm 0.07 \#$ & $0.19 \pm 0.05 \#$ & $3.82 \pm 0.31$ & $0.06 \pm 0.01 \#$ \\
\hline $\mathrm{Pb}+\mathrm{DMSA}+\mathrm{VC}$ & $0.34 \pm 0.01 \#$ & $0.25 \pm 0.03 \#$ & $3.89 \pm 0.08$ & $0.07 \pm 0.05 \#$ \\
\hline $\mathrm{Pb}+\mathrm{VC}$ Only & $0.20 \pm 0.02 \#$ & $0.22 \pm 0.04 \#$ & $4.53 \pm 0.15$ & $0.05 \pm 0.01$ \\
\hline
\end{tabular}

The above table shows effects of $L$. taraxacifolia on some liver function test in sub-chronic lead poisoning:

$\mathrm{VEH}=$ Distilled water

$\mathrm{Pb}=$ Lead

$\mathrm{VC}=$ Vitamin $\mathrm{C}$ or ascorbic acid

DMSA = Dimecarptosuccinic acid

$\mathrm{LT}=$ Launaea taraxacifolia

LTP = Launaea taraxacifolia $(100 \mathrm{mg} / \mathrm{kg})$ before lead treatment

$\mathrm{GSH}=$ Reduced gluthatione

SOD = Superoxide dismutase

* = significant $p$ value when compared with VEH

\# =significant $\mathrm{p}$ value when compared with $\mathrm{Pb}$ only

- = significant $p$ value when compared with DMSA + VC treated group

$\mathrm{Q}=$ significant $p$ value when compared with DMSA $+\mathrm{LT}(100 \mathrm{mg} / \mathrm{kg})$ only treated group

of the group treated with $\mathrm{Pb}$ only when compared with the groups treated with distilled water only (VEH), while there was significant decrease in the $p$ value in ALT and AST of all the group treated when compared with group treated with $\mathrm{Pb}$ only. Also, the result revealed decreased $(p<0.05)$ value of ALT in groups treated with VC only and $100 \mathrm{mg} / \mathrm{kg}$ when compared groups treated with DMSA + VC and DMSA + LT respectively. In addition, the $p$ value of AST in group treated with $100 \mathrm{mg} / \mathrm{kg}$ and DMSA only was significantly decreased and increased respectively when compared with DMSA + LT (100 mg/kg). However, there was no significant change in serum albumin concentration in all the treated groups when compared with $\mathrm{Pb}$ only. Whereas, there was significant reduction in $(p<0.05)$ in serum glucose level of $\mathrm{Pb}$ only treated group when compared with $\mathrm{VEH}$, while there was significant increase $(p<0.05)$ in serum glucose level of the groups treated with $100 \mathrm{mg} / \mathrm{kg}$, DMSA only and DMSA + VC when compared with $\mathrm{Pb}$ only.

Moreover, Table 3 shows that, there was significant increase in $(p<0.05)$ in serum level of catalase (CAT), reduced Glutathione (GSH) and Superoxide Dismutase (SOD) in all the treated groups when compared with the group treated with $\mathrm{Pb}$ only. Likewise, there was significant increase in $p$ values of GSH in groups treated with $\mathrm{VC}$ only when compared with group treated with $\mathrm{DMSA}+\mathrm{VC}$, while the result revealed increase in GSH and catalase of groups treated with DMSA+LT when compared with DMSA only treated group. However, there was decrease $p$-value in SOD of the groups treated with $100 \mathrm{mg} / \mathrm{kg}$ of LT only when compared with group treated with $\mathrm{Pb}+\mathrm{DMSA}$, while the $\mathrm{p}$ value in SOD of combination therapy are significantly increased when compared with the groups treated with DMSA only.

\section{Discussion}

Lead is hazardous to health, and it remains a global risk to public health. Liver serves multiple functions such as biotransformation of insoluble compounds, production of plasma proteins, metabolism of amino acids, carbohydrates, lipid etc. Liver is a vital metabolizing organ in the body, known to play a major role in lead metabolism [14]. Therefore, accumulation of lead in the liver accounts for deleterious effects on the body system [15].

Blood lead level (BLL) is a biomarker for analysis of Lead toxicity. In this study significant increase in BLL after administration of lead acetate in drinking water in a dose of $0.2 \%$ for 5 weeks consecutively in groups treated with lead only was demonstrated, thus revealing the effect of lead poisoning in blood. This study also demonstrated the effectiveness of DMSA in decreasing blood lead levels. However, it has been reported that plants develop a complex mechanism by which they control the uptake and accumulation of heavy metals, therefore, significant reduction in BLL in the groups treated with the three doses of the extract shows the ameliorative effect of LT. Meanwhile, combination therapy (DMSA + VC, DMSA + LT) points to a possibility that the LT might be facilitating the entry of strong lipophilic chelator like DMSA for an effective mobilization of lead [16,17].

Moreover, there was increase in urinary lead elimination in all the treated groups and reduction in ULL of lead in rat exposed to lead only, this supports the fact that, DMSA, LT and combination 
Table 3 Effects of L. taraxacifolia on Glutathione reductase (GSH), Catalase and Superoxide Dismutase (SOD) in Sub - Chronic Lead Poisoning.

\begin{tabular}{|c|c|c|c|}
\hline & \multicolumn{3}{c|}{ MEAN VALUES \pm SEM } \\
\hline Groups & GSH (mg/dl) & CATALASE (mg/dl) & SOD (mg/dl) \\
\hline VEH (No Lead) & $0.70 \pm 0.06$ & $0.65 \pm 0.01$ & $0.59 \pm 0.05$ \\
\hline $\mathrm{Pb}$ only & $0.38 \pm 0.02 *$ & $0.33 \pm 0.06^{*}$ & $0.24 \pm 0.06 *$ \\
\hline $\mathrm{LT}$ before Pb & $0.69 \pm 0.03 \#$ & $0.47 \pm 0.02 \#$ & $0.62 \pm 0.08 \#$ \\
\hline $\mathrm{Pb}+50 \mathrm{mg} / \mathrm{kg}$ & $0.56 \pm 0.04 \#$ & $0.66 \pm 0.01 \#$ & $0.67 \pm 0.06 \#$ \\
\hline $\mathrm{Pb}+100 \mathrm{mg} / \mathrm{kg}$ & $0.48 \pm 0.01 \# \mathbf{0}$ & $0.63 \pm 0.01 \#$ & $0.85 \pm 0.07 \# \mathbf{0}$ \\
\hline $\mathrm{Pb}+200 \mathrm{mg} / \mathrm{kg}$ & $0.75 \pm 0.09 \#$ & $0.61 \pm 0.02 \#$ & $1.09 \pm 0.01 \#$ \\
\hline $\mathrm{Pb}+\mathrm{DMSA}$ only & $0.55 \pm 0.02 \#$ & $0.61 \pm 0.02 \#$ & $0.75 \pm 0.09 \#$ \\
\hline $\mathrm{Pb}+\mathrm{DMSA}+\mathrm{LT}(100 \mathrm{mg} / \mathrm{kg})$ & $0.91 \pm 0.14 \# \mathbf{0}$ & $0.63 \pm 0.01 \#$ & $1.28 \pm 0.29 \# \mathbf{0}$ \\
\hline $\mathrm{Pb}+\mathrm{DMSA}+\mathrm{VC}$ & $0.58 \pm 0.04 \#$ & $1.29 \pm 0.18 \#$ & $1.45 \pm 0.210$ \\
\hline $\mathrm{Pb}+\mathrm{VC}$ Only & $0.92 \pm 0.12 \# \bullet$ & $1.03 \pm 0.07 \#$ & $1.48 \pm 0.11 \#$ \\
\hline
\end{tabular}

The above table shows effects of $\mathrm{L}$. taraxacifolia on glutathione reductase, catalase and superoxide dismutase in sub - chronic lead poisoning: $\mathrm{VEH}=$ Distilled water

$\mathrm{Pb}=$ Lead

VC= Vitamin C or ascorbic acid,

DMSA = Dimecarptosuccinic acid,

$\mathrm{LT}=$ Launaea taraxacifolia, .

LTP = Launaea taraxacifolia $(100 \mathrm{mg} / \mathrm{kg})$ before lead treatment.

$\mathrm{GSH}=$ Reduced gluthatione

SOD = Superoxide dismutase

* = significant $\mathrm{p}$ value when compared with $\mathrm{VEH}$,

\# = significant $\mathrm{p}$ value when compared with $\mathrm{Pb}$ only

- = significant $p$ value when compared with DMSA only treated group

$\mathrm{D}=$ significant $p$ value when compared with DMSA $+\mathrm{LT}(100 \mathrm{mg} / \mathrm{kg})$ treated group

- = significant $p$ value when compared with DMSA + VC treated group

therapy all enhance urinary lead elimination. However, vitamin C only was observed to have capability of diminishing lead toxicity in Wistar rats; this effect may be due to its antioxidant effect rather than being a chelating agent, because disruption of prooxidant/antioxidant balance might have led to the tissue injury [18].

Elevation of liver enzyme (ALT and AST) which serves as marker for liver damage was observed in group that received sub-chronic administration of lead only, while there was reduction in groups treated with three doses of the extract, especially groups treated with $100 \mathrm{mg} / \mathrm{kg}$ before and after lead administration. Meanwhile, no significant change in ALT and AST observed in groups treated with DMSA only and combination therapy may be due to the effect of DMSA on liver enzyme [19]. This implies that the management of lead poisoning using LT is desirable. This study compared the effect of DMSA with LT, the results showed better improvement in reduction of aspartate transaminase (AST) in groups treated with $100 \mathrm{mg} / \mathrm{kg}$ and combination of DMSA with LT. In addition, the group treated with vitamin C alone showed better improvement in reduction of ALT than the group treated with DMSA + VC. This study further showed the damaging effect of DMSA and ameliorative effect of LT and vitamin C in the management of lead poisoning. Likewise, antioxidants used in monotherapy or in conjunction with chelators have been shown to result in alleviated symptoms of lead poisoning along with the diminished side effect [20]. Although, blood glucose levels were reported to be reduced by lead, due to toxic effects of lead on glucose metabolism but have shown that DMSA is effective in improving the low blood glucose in lead poisoning
[21]. Interestingly, this study also revealed the reduction of blood glucose in the groups that received lead only, significant increase in serum glucose level in the group treated with $100 \mathrm{mg} /$ $\mathrm{kg}$ of $\mathrm{LT}$, the result is similar to groups treated with DMSA and combination of DMSA + LT. This suggests that, LT improves the hypoglycemic state caused by lead poisoning and also potentiate the effect of DMSA in sub chronic lead poisoning. However, no change in albumin level in all the tested groups, this suggests that neither lead nor LT bind to albumin, and it also signifies the stability of albumin level in sub chronic phase of lead poisoning in Figure 1.

Lead alters antioxidant activities by inhibiting functional $\mathrm{SH}$ groups in several enzymes such as, Superoxide dismutase (SOD), Catalase (CAT), reduced Glutathione (GSH). GSH, CAT, and SOD are potential targets for lead toxicity. The result observed during this study revealed tremendous improvement in antioxidant activity in groups treated with vitamin C only, LT and co administration with DMSA. Likewise, administration of the extract before lead exposure also show significant improvement in preventive effect against lead-induced oxidative stress by means of increasing SOD, catalase activity, and glutathione (GSH) content in rats. As earlier stated, Vitamin $\mathrm{C}$ has a possibility of serving as chelator of lead [22].

Accumulation of significant amount of lead in liver tissue results in oxidative stress response in the liver [23]. Sivaprasad in 2003 reported that, administration of Vitamin C without a chelator had a significant ability to prevent lipid peroxidation in leadexposed rats. In agreement with Sivaprasad, this study has also demonstrated preventive and ameliorative effects of LT 
A. Distilled Water only

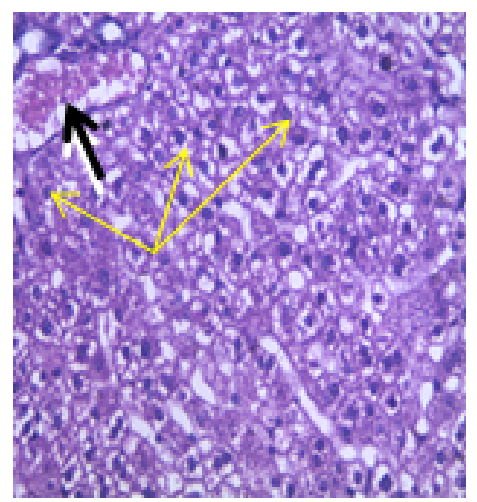

B. Lead only

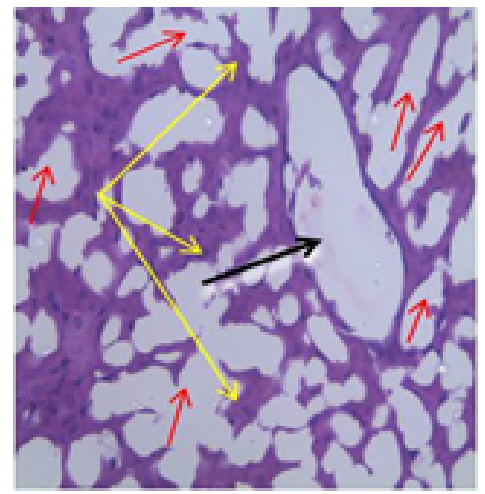

\section{C. $100 \mathrm{mg} / \mathrm{kg}$ of LT before $\mathrm{Pb}$}

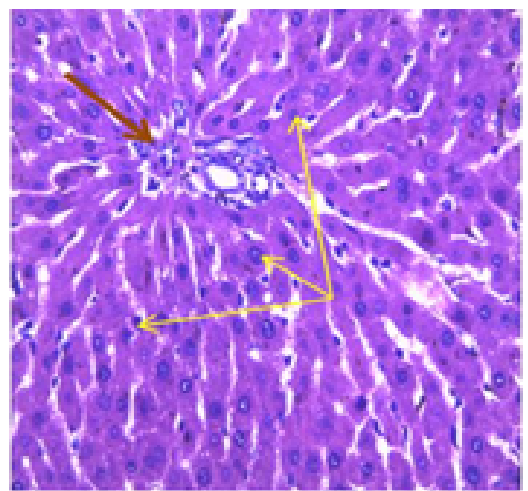

\section{D. $\mathrm{Pb}+50 \mathrm{mg} / \mathrm{kg}$ of $\mathrm{LT}$}

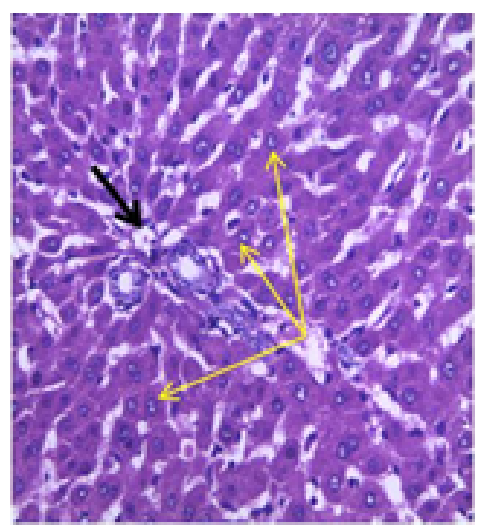

\section{E. Pb $+100 \mathrm{mg} / \mathrm{kg}$ of $\mathrm{LT}$}

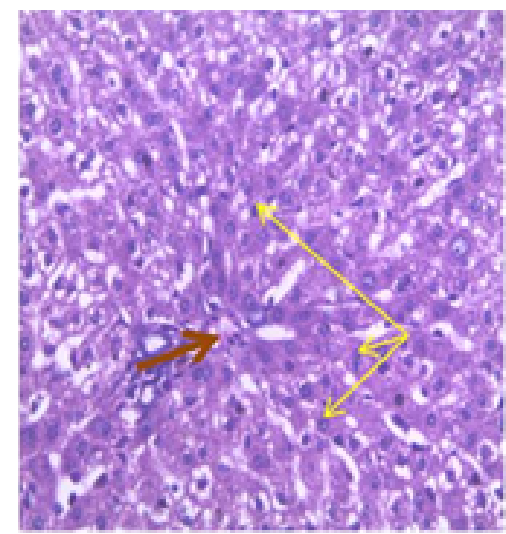

$\mathrm{F} . \mathrm{Pb}+200 \mathrm{mg} / \mathrm{kg}$ of $\mathrm{LT}$

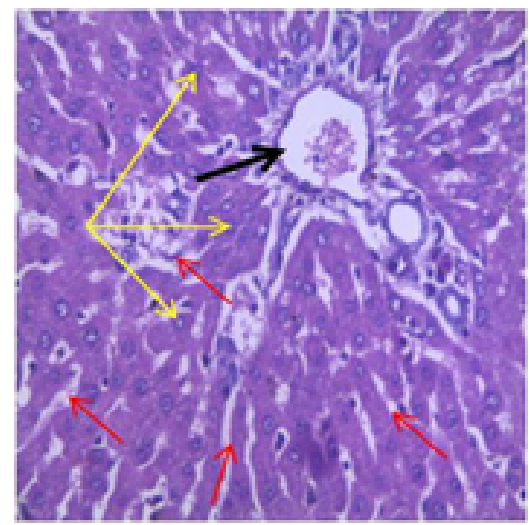

Figure 1 Photomicrograph of the liver X400.

Figure A possesses radially arranged hepatocytes (yellow arrows) around the central vein (black arrow) but B shows various degrees of vacuolation (red arrow). Microscopically, coat of the central vein of figure $\mathbf{C}$ and $\mathbf{E}$ was thickened (brown arrow) and reduced central vein (brown arrow). However, $\mathbf{F}$ has disorganized outline with very few hepatocytes, but normal central vein (black arrow). All the figures apart from $\mathbf{A}$ and $\mathbf{E}$ possess vacuolated cytoplasm. Pb - Lead, LTLaunaea taraxacifolia, LTP- $100 \mathrm{mg} / \mathrm{kg}$ of Launaea taraxacifolia before lead.

(especially $100 \mathrm{mg} / \mathrm{kg}$ before and after lead administration) and Vitamin $C$ on lead poisoning. This may also be due to the fact that, vitamin $\mathrm{C}$ has pro- antioxidant and cyto- protective effect, therefore, prevents oxidative stress on liver damage [24].

Moreover, accumulation of significant amount of lead subjected the liver to proliferating hepatocytes surrounded by scar tissues termed fibrosis, a key feature of progressive liver damage $[25,26]$. From this study, it was confirmed through the histological findings from the examination of liver tissues in rats treated with LT for 21 days that, most of the histological alterations induced by all the group were markedly reversed except treatment with lead only. Photomicrographs of all the treated groups showed minimal alterations when compared to the lead acetate treated rats. These findings indicate that the 3 doses of LT, Vitamin C, DMSA and combination therapy have therapeutic effect against hepatotoxicity. It also confirms the protective effect of LT in Figure 2.
Lead poisoning due to accidental exposure is a major risk to health in some communities in Africa. Extract from L. taraxacifolia, a common vegetable in West Africa holds some potential in mitigating the toxic effect of lead intoxication if taken regularly. It could be speculated that the rich phytochemical constituents, particularly antioxidant in LT, may be responsible for its ameliorative and protective properties observed in this study.

\section{Conclusion}

This study concluded that, leaf extract of Launaea taraxacifolia has ameliorative and preventive effect on hepatotoxicity of lead poisoning, thereby supporting its ethno medicinal use in the management of poisoning. 


\section{G. Distilled Water only}

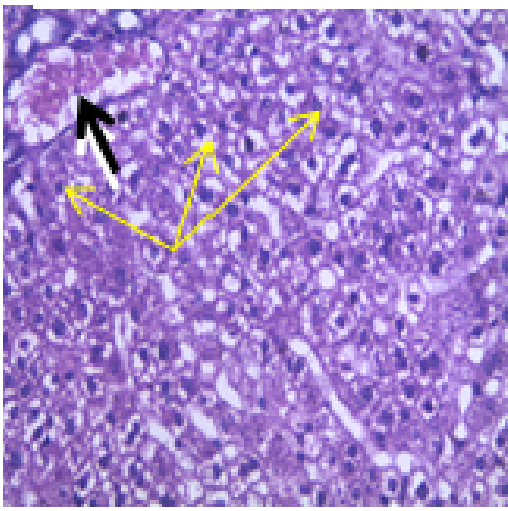

H. Lead only

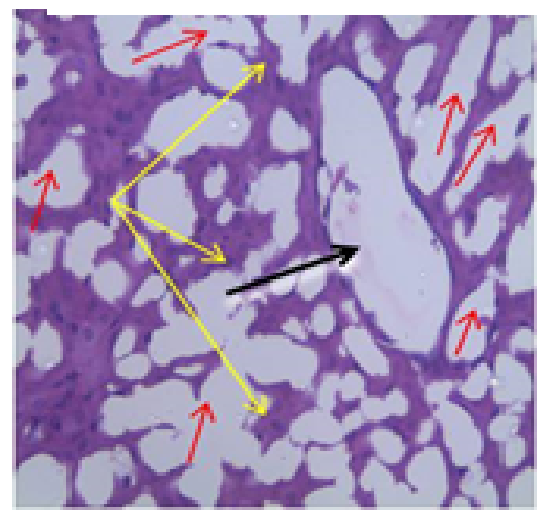

I. $\mathrm{Pb}+\mathrm{DMSA}$

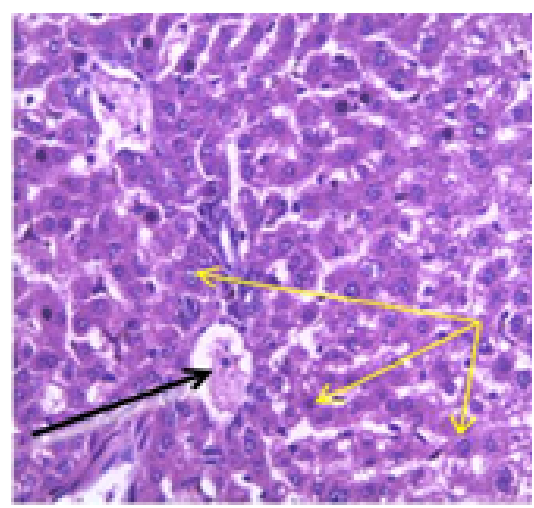

J. $\mathrm{Pb}+\mathrm{DMSA}+\mathrm{LT}$

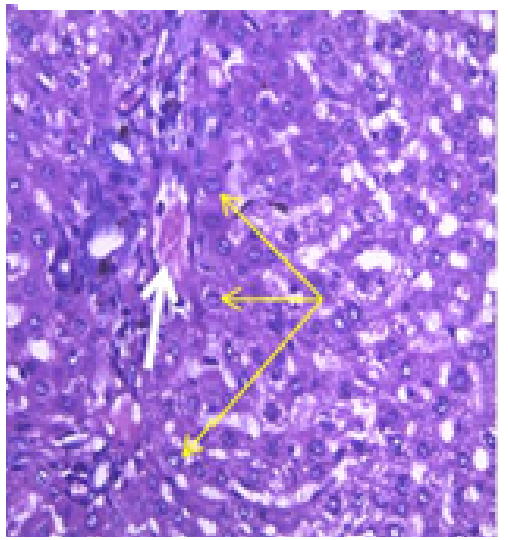

K. $\mathrm{Pb}+\mathrm{DMSA}+\mathrm{VC}$

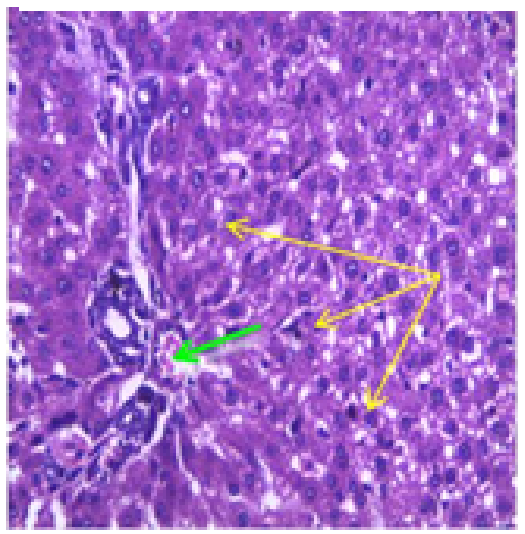

L. $\mathrm{Pb}+\mathrm{VC}$

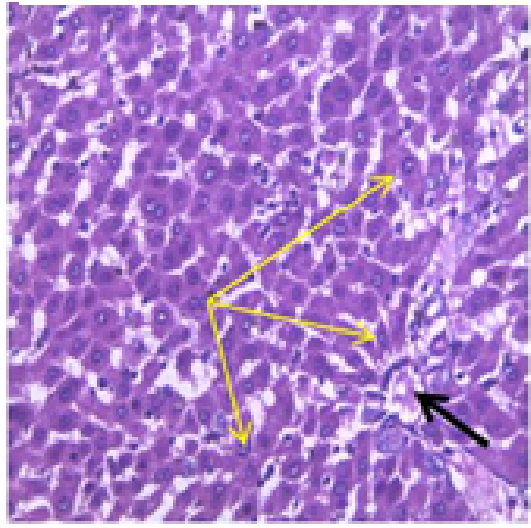

Figure 2 Photomicrograph of the liver X400 (CONTD).

Figure $\mathbf{G}$ and $\mathbf{H}$ have normal microstructure, i.e., normal hepatocytes (yellow arrows) and central vein (black arrow), figure $\mathbf{H}$ shows various degrees of vacuolation (red arrow), while thickening of venous wall and necrosis was seen in figure $\mathbf{J}$ (white arrow), coat of the central vein of figure $\mathbf{K}$ was thickened (green arrow). However, figure $\mathbf{L}$ possesses well spread out hepatocytes which are radially arranged around the central vein. Pb- Lead, LT - Launaea taraxacifolia, DMSA - Dimecaptosuccinic acid, VC - Vitamin C.

\section{Recommendation}

Consumption of L. taraxacifolia can be helpful in the elimination of Lead $(\mathrm{Pb})$ which accumulates accidentally.

\section{Acknowledgement}

The non-academic staff of animal holding department and pharmacology department, Obafemi Awolowo University, Ile-Ife.

\section{Declarations}

Funding: Self

Conflict of interest: None

Ethical approval: This study was approved by the University Research Committee (URC) on 25 th of October, 2016 with registration number, $\mathrm{PHP} / 12 / 13 / \mathrm{H} 0602$.

\section{References}

1 Tong S, Von Schirnding Y, Prapamontol T (2000) Environmental lead exposure: a public health problem of global dimensions. Bull WHO 78: 1068-1077.

2 Laraque D, Trasande L (2005) Lead poisoning: successes and 21st Century Challenges. Pediatr Rev 26: 435-443.
3 Needleman H (2009) Low level lead exposure: history and discovery. Ann Epidemiol 19: 235-238.

4 WHO (2013) Guidelines for drinking water quality, $2^{\text {nd }}$ Edn, Vol. 1, Recommendations, Geneva J Am Sci: 9(2s).

5 Jennifer AL (2012) Oral chelation therapy for patients with lead poisoning; Textbook of clinical pharmacology and medical toxicology. Oxford incorporated. Oxford Pp: 2-124. 
6 Patrick L (2006) Lead toxicity part II: the role of free radical damage and the use of antioxidants in the pathology and treatment of lead toxicity. Qatar Med J 11: 2-22

7 Schippers RR (2000) African indigenous vegetables; an overview of the cultivated species. Natural Resources Institute/AVEH-EU Technical Centre for Agricultural and Rural Cooperation, Chatham, United Kingdom, P: 214.

8 Aboderin FI, Olajide JS, Adesiyan A (2017) Toxicity effect of Launaea taraxacifolia aqueous extract on vital organs of albino rat. Int $J$ Biochem Biophys Mol Biol 2: 47-50.

9 Arawande JO, Amoo IA, Lajide L (2013) Chemical and phytochemical composition of wild lettuce Launaea taraxacifolia. J Applied Phytotechnology in Environmental Sanitation 2: 25-30.

10 Adinortey MB, Sarfo JK, Quayson ET, Weremfo A, Adinortey CA, et al. (2012) Phytochemical screening, proximate and mineral composition of Launaea taraxacifolia leaves. Res J Med Plant 6: 171-179.

11 Thomford NE, Mkhize B, Dzobo K, Mpye K, Rowe A, et al. (2016) African lettuce (launaea taraxacifolia) displays possible anticancer effects and herb-drug interaction potential by cyp1a2, cyp2c9, and cyp2c19 inhibition. J Integ Biol 20: 528-537.

12 Adejuwon SA, Femi-Akinlosotu O, Omirinde JO (2015) Cisplatininduced testicular dysfunction and its amelioration by Launaea taraxacifolia leaf extract. Andrologia 47: 553-559.

13 Adejuwon A, Femi-Akinlosotu O, Omirinde J, Owolabi O, Afodun A (2014) Launaea taraxacifolia ameliorates cisplatin-induced hepatorenal injury. Eur J Med Plant 4: 528.

14 Khaled MAA, Abeer MRH (2008) Therapeutic efficacy of alpha lipoic acid in combination with succimer against lead-induced oxidative stress, hepatotoxicity and nephrotoxicity in rat. Bull Environ Res 11: 87-99.

15 Mudipalli A (2007) Lead hepatotoxicity and potential health effects. Indian J Med Res 126: 518-527.

16 Iwalewa EO, Adewunmi CO, Omisore NO, Adebanji OA, Azike CK
(2005) Pro-antioxidant effects and cytoprotective potentials of nine edible vegetables in Southwest Nigeria. J Med Plant 8: 539-54423.

17 Flora G, Gupta D, Tiwari A (2012) Toxicity of lead: a review with recent updates. Interdiscip Toxicol 5: 47-58.

18 Bradberry SI, Vale AA (2009) Comparison of sodium calcium edetate (edetate calcium disodium) and succimer (DMSA) in the treatment of inorganic lead poisoning. Clin Toxicol 47: 841-858.

19 Khaki A, Khaki A (2010) Antioxidant effect of ginger to prevents leadinduced liver tissue apoptosis in rat. J Med Plant Res 4: 1492-1495.

20 Flora S, Pande M, Mehta A (2003) Beneficial effect of combined administration of some naturally occurring antioxidants (vitamins) and thiol chelators in the treatment of chronic lead intoxication. Chem Biol Interact 43: 267-280.

21 Ashour AAE, Yassin MM, Abubasi NM, Ali RM (2007) Blood serum glucose and renal parameters in lead-loaded albino rats and treatment with some chelating agents and natural oils. Turk J Biol 31: 25-34.

22 Koukoui O, Agbangnan P, Boucherie S, Yovo M, Nusse O, et al. (2015) Phytochemical study and evaluation of cytotoxicity, antioxidant and hy-polipidemic properties of launaea taraxacifolia leaves extracts on cell lines hepg2 and plb985. Am J Plant Sci 6: 1768-1779.

23 Valko M, Leibfritz D, Moncol J, Cronin MT, Mazur M, et al. (2001) Free radical and antioxidants in normal physiological functions and human disease. Int J Biochem Cell Biol 3: 147-153.

24 Sivaprasad TR, Nagaraj M, Varalakshmi P (2003) Combined efficacies of lipoic acid in combination with 2,3-dimercaptosuccinic acid on lead-induced erythrocyte membrane peroxidation and antioxidant status in rats. Hum Exp Toxicol 4: 183-192.

25 Adinortey MB, Ansah C, Weremfo A, Adinortey CA, Adukpo CE, et al. (2018) DNA Damage Protecting Activity and Antioxidant Potential of Launaea taraxacifolia Leaves Extract. J Nat Sc Biol Med 9: 6-13.

26 Adnan W. Al-Bideri (2007) Histopathological study on the effect of antioxidants (Vitamin E and selenium) in hepatotoxicity induced by lead acetate in rats. Qual Med J 7: 143-155. 